\title{
Éditorial
}

\section{Perception et action dans les interactions complexes avec l'environnement}

$\mathrm{Au}$ cours de ces trente dernières années, le nombre des études sur les liens entre perception et action a considérablement augmenté dans le cadre pluridisciplinaire des sciences du mouvement. Ce développement est très certainement lié à l'apparition de besoins et d'objectifs nouveaux mais aussi de technologies qui ont très rapidement évolué. Ce développement combiné a permis de porter un regard nouveau sur les phénomènes complexes tels que ceux rencontrés dans les activités physiques et sportives et d'une manière plus générale dans les interactions de l'être humain avec son environnement.

Concernant les questions posées au plan scientifique et les liens entre perception et action, il s'agit de comprendre quelles sont les informations disponibles et comment ces informations sont utilisées pour produire et réguler le mouvement. Il faut dire ici que ces questions ont fait l'objet de nombreux débats et controverses. Si certains ont pu penser que ces oppositions étaient stériles ou que certaines positions n'étaient pas tenables, une autre conception consiste à y voir un caractère stimulant et structurant qui permettra à terme d'aboutir à une compréhension intégrée des mécanismes mis en jeu.

La compréhension des mécanismes perceptivomoteurs impliqués dans ces interactions est un véritable challenge. En effet, pour étudier ces mécanismes, il est nécessaire de ne pas dénaturer les contraintes environnementales et de les examiner in vivo ou pour le moins en préservant la complexité qui les caractérise. Le problème est qu'en procédant ainsi, il devient extrêmement difficile d'isoler les variables pour analyser et comprendre les comportements étudiés. Les progrès technologiques associés à l'ingéniosité des chercheurs permettent peu à peu de dépasser ces difficultés.

Parmi les nouveaux outils disponibles, les systèmes de capture du mouvement qui permettent l'analyse de la motricité corporelle ou oculaire ont largement évolué avec des dispositifs variés de plus en plus précis, simples d'utilisation et de moins en moins onéreux. Le développement de la réalité virtuelle donne la possibilité de créer et de manipuler des environnements interactifs de plus en plus complexes. Les dispositifs d'imagerie cérébrale (EEG, IRMf, TEP par exemple) permettent d'identifier de plus en plus précisément les structures impliquées dans les phénomènes perceptifs et moteurs. Enfin les outils logiciel d'analyse permettent de traiter des masses de données considérables (aussi appelées «Big Data ») et d'extraire des variables résumant la complexité. Cet ensemble d'outils offre des possibilités d'investigations de grande ampleur qui se traduisent par des recherches de plus en plus avancées dans la compréhension des processus perceptifs et moteurs.

En termes d'applications, ces recherches peuvent alimenter de nombreux domaines tels que ceux des apprentissages, de la performance, de la rééducation ou de la réathlétisation. Elles peuvent contribuer à améliorer les possibilités se déplacer en milieux urbain, marin ou aérien pour lesquels de nouvelles interfaces peuvent rendre les informations plus accessibles ou faciliter et rendre plus sûr les déplacements. Elles alimentent aussi la sphère des jeux vidéo et des «serious games » dans laquelle les concepteurs utilisent très directement les données de la psychophysique et du contrôle du mouvement pour réaliser des jeux de plus en plus immersifs et interactifs. Très connecté à ces deux derniers domaines, il y a enfin le domaine de la robotique où les données sur les interactions individu-environnement permettent de concevoir des robots capables de s'adapter à des situations de plus en plus complexes.

Dans cet ensemble très riche et prolifique, le but de ce numéro spécial de «Movement and Sport Sciences Science \& Motricité $»$ est de rassembler un ensemble de contributions sur les liens entre Perception et Action dans les interactions complexes avec l'environnement. Cet ensemble est bien sûr loin d'être exhaustif (et plusieurs numéros spéciaux pourraient être réalisés sur ce sujet), mais il a pour but de donner des éclairages variés sur certaines questions essentielles qui caractérisent ce champ de recherche. Ce numéro commence par un premier article sur les approches théoriques du développement et le rôle essentiel des cycles de perception et d'action dans 
l'exploration et la découverte de possibilités d'action (Williams et al.). La question de la perception visuelle dans ses versants directs et indirects est abordée à travers les contributions de Lanwerh et al. et Bennett, la première portant sur l'estimation du temps lors d'approche de cible, la seconde portant sur le rôle des mouvements oculaires dans l'extrapolation de trajectoires. Le rôle de la cognition est notamment abordé dans la contribution de Lebon et al. qui présente les intérêts et les limites du rôle de l'observation pour l'apprenant dans l'acquisition des habiletés perceptivo-motrices. Les approches dynamiques sont également représentées d'abord à partir d'une conception nouvelle des processus décisionnels à travers les niveaux micros et macros des équipes de sport collectifs pour rendre compte de différents niveaux d'organisation des situations complexes (Araujo et al.). La question de la variabilité est ensuite traitée dans son rôle fonctionnel et prend support ici de l'expertise dans la production et la régulation du mouvement
(Komar et al.). Enfin, l'utilisation de la réalité virtuelle est illustrée à travers l'exemple du tir de coup franc en football du point de vue et pour l'action du gardien de but avec toute la complexité inhérente à cette situation (Brault et al.).

$\mathrm{Au}$ final, la plupart de ces contributions font un état de l'art de leur domaine de recherche respectif. Elles fourniront ainsi une vision synthétique de certains enjeux, de possibilités d'investigations et de connaissances qui caractérisent les liens entre perception et action.

Très bonne lecture!

Nicolas Benguigui

CESAMS (Centre d'Études Sport et Actions MotriceS)

EA 4260

Université de Caen Normandie 


\section{Editorial}

\section{Perception and action in the complex interactions with the environment}

During the last thirty years, studies on the links between perception and action have developed considerably thanks to multidisciplinary work in the movement sciences. This development is certainly due to better understanding and new objectives, but also to technologies which have very quickly evolved over this period. The work has given rise to new perspectives on complex phenomena such as those encountered in physical and sports activities, and in a more general way in the interactions of human beings with their environment.

In any consideration of the scientific issues addressed when studying the links between perception and action, the primary questions come down to what are the available sources of information, and how is information used to choose, produce, and regulate the movement. These questions were the object of numerous debates and controversies. If some researchers considered these controversies unfruitful, or that certain positions were untenable, an alternative interpretation is that they were stimulating and provided a foundation that would lead to an integrated understanding of the involved processes.

Comprehension of the perceptuo-motor mechanisms involved in human interaction with its environment is a real challenge. Indeed, to study these mechanisms, it is necessary not to distort environmental constraints and to examine them in vivo or at least while maintaining the complexity which characterizes them. The problem is that so by proceeding, it becomes extremely difficult to isolate the relevant variables and to analyze and understand the behavior. Technological progress coupled with the ingenuity of researchers has progressively led to overcoming these difficulties.

Among the most advanced of the tools that have been developed, several deserve to be mentioned. Motioncapture systems, which allow the analysis of body or eye movements, have significantly diversified while becoming more accurate, easier to use, and less expensive. The development of virtual reality has made it possible to create and manipulate more and more complex interactive environments. Brain imaging systems (EEG, IRMf, TEP for example) allow more and more accurate identification of the structures involved in perceptual and motor processes. Finally, software tools for data and statistical analysis can handle large data sets (big data) and extract variables summarizing various aspects of complex systems. This set of devices offers possibilities for large-scale investigations which result in more and more advanced research into perceptive and motor processes.

In terms of applications, current research feeds numerous domains such as those of learning, performance, reeducation, and rehabilitation. It has improved understanding and realization of human-machine interfaces which facilitate travel on land, water, and air, and which for this issue are especially relevant to examination of perceptual access to information. The research also contributes to the development the video games, especially of "serious games" in which the designers use very directly the data of psychophysics and motor control to create games that are more and more immersive and interactive. Enmeshed in these areas of research is the domain of robotics where the knowledge about individualenvironment interactions has led to robots capable of acting in more and more complex situations.

In this very rich and prolific context, the purpose of this special issue of Movement and Sport Sciences Science \& Motricité is to gather a set of contributions dealing with the links between perception and action in complex interactions with an environment. These contributions are of course far from being exhaustive (several issues could be made on these subjects), but this issue aims to illuminate certain questions which characterize this field of research.

This issue begins with an article on the theoretical approaches to the development of reaching behaviors and the essential role of repeated cycles of perception and action in the exploration and discovery of possibilities of action (Williams et al.). The question of visual perception in its direct and indirect aspects is approached through the contributions of Lanwerh et al. and Bennett, the first concerns the estimation of time during the approach of a target, the second concerns the role of eye movements in the extrapolation of trajectories. The role of cognition 
is addressed in particular in the contribution of Lebon et al. who lay out the utility and limitations of the role of observation in perceptuo-motor skill learning. The dynamic approaches are also represented, first in a new conception of decision-making by means of micro and macro levels of examination of team sports in order to summarize various levels of organization in complex situations (Araujo et al.). The question of variability is then addressed in its functional role, addressed with respect to expertise in the production and regulation of movement (Komar et al.). Finally, the use of virtual reality is illustrated with the example of the free kick in soccer from the goalkeeper's point of view relative to his or her action, with all the complexity inherent to this situation (Brault et al.).
In the end, most of these contributions are state of the art in their respective domain of research. They provide a synthesis of different visions of their respective questions, of possible future investigations, and of the knowledge which characterizes the links between perception and action.

Enjoy reading!

Nicolas Benguigui

CESAMS (Centre d'Études Sport et Actions MotriceS)

EA 4260

Université de Caen Normandie 